\title{
FOTOFILIA: Nuevas miradas sobre la topofilia a través de la fotografía
}

\section{FOTOFILIA: Novas visões sobre a topofilia através da fotografia}

\section{PHOTOPHILIA: New views about topophilia through photography}

\author{
Maya Corredor \\ artistucha@hotmail.com \\ Facultad de Bellas Artes de la Universidad Pedagógica Nacional de Colombia \\ Corporación Unificada Nacional de Educación Superior
}

\section{RESUMEN}

Con un grupo de niños, niñas y jóvenes de Altos de Cazucá, Soacha (Colombia), se ha desarrollado un proceso de Investigación Acción Participativa basado en la relación que ellos tienen con su entorno -atravesado por graves problemáticas políticas, sociales y medio ambientales-. Esta experiencia se inició en marzo de 2010 y continúa actualmente con la exploración en torno al término topofilia, que se refiere a la relación filial, positiva y creativa que tenemos con ese espacio que apropiamos como "nuestro lugar". Esta noción está acompañada por su opuesta, la topofobia.

El grupo de participantes ha podido elaborar y resignificar la relación con sus hogares, barrio y entorno cotidiano. El marco de sentido y metodológico de la Investigación Acción Participativa ha facilitado que el colectivo apropie y enriquezca los términos topofilia y topofobia con nuevos significados, más cercanos a sus formas particulares de sentir, habitar y transformar sus lugares. Lo cual ha incidido positivamente en la forma cómo ellos se asumen en la vida en comunidad. La fotografía fue utilizada aquí como el medio fundamental de exploración e indagación, y fue aprovechada en su potencial imaginativo e inventivo, más que documental. De esta manera, el grupo ha aportado algunos puntos de encuentro entre la fotografía y la topofilia, como espacios de afectividad, empoderamiento, autoreconocimiento, autocontención, apropiación y creatividad. Esta relación fue llamada por ellos fotofilia.

Palabras-claves: topofilia, topofobia, fotografía, investigación acción participativa.

\section{RESUMO}

Com um grupo de crianças e jovens em Altos de Cazucá, Soacha (Colômbia), foi desenvolvido um processo de pesquisa-ação participativa com base na relação que eles têm com seu ambiente, passando por graves problemas políticos, sociais e ambientais-. Esta experiência nasceu em março de 2010 e continua até hoje com a exploração em torno do termo topophilia , que se refere à relação filial, positiva e criativa com o espaço que apropriamos como o nosso "lugar". Esta noção é acompanhada por seu oposto, topofobia. 
Durante este tempo o grupo de participantes foi capaz de se desenvolver e reinterpretar a relação com suas casas do bairro, e ambiente de vida. O significado e a estrutura metodológica do IAP forneceu o coletivo aproprie e enriqueça os termos topophilia - topofobia com novos significados, mais pertos de suas formas particulares de sentir, e transformar seus lugares de vida. Isto teve um impacto positivo na forma como assumen a vida deles em comunidade. A fotografia foi usada por eles como o principal meio de exploração e investigação, e foi aproveitada em potencial imaginativo e inventivo, ao invés de documentário. Assim, o grupo tem proporcionado alguns pontos em comum entre a fotografia e a topophilia como espaços de emoções, empoderamento, auto-reconhecimento, auto-suficiencia, propriedade e criatividade. Esta relação foi chamada por eles fotofilia.

Palavras-chave: topophilia, topofobia, fotografia, pesquisa-ação participativa.

\section{ABSTRACT}

Participatory Action Research was conducted with children and adolescents from Altos de Cazucá, Soacha (Colombia) facing serious social, political, and environmental problems in their communities. This experience began in March of 2010 and continues to explore topophilia, which refers to: family, positive, and creative relationships that we have with our place, and which we appropriate as "our place." This concept is accompanied by its opposite, topophobia.

The participants have developed and re- signified the relationship with their homes, neighborhood, and daily surroundings through this process. The methodological framework of Participatory Action Research has facilitated the collective appropriation and enrichment of the terms topophilia and topophobia with new meanings, closer to the participants' own ways of feeling, living, and transforming their places. The experience has been a positive intervention in the way that they live in their community. Photography was a central means of exploration and research. Beyond its documentary capacity, it stimulated the participants' imagination. The group found an affinity between photography and topophilia as spaces of affection, empowerment, self-recognition, internal debate, appropriation, and creativity. They called this relationship photophilia.

Keywords: topophilia, topophobia, photography, participatory action research 


\section{INTRODUCCIÓN}

Este artículo pretende ampliar algunas de las reflexiones producidas en el curso de la experiencia de Investigación Acción Participativa (IAP) desarrollada con un grupo de aproximadamente 15 niños, niñas y jóvenes en el territorio Altos de Cazucá-Colombia. Esta experiencia consiste en la indagación, acción y reflexión respecto a la relación que ellos entablan con su entorno, con el rico entramado de elementos que componen sus hogares, barrio y medio ambiente. En esta indagación, la imagen fotográfica ha sido el catalizador de los encuentros reflexivos entre los jóvenes y su hábitat. El término topofilia, que se dirige básicamente a dar relieve al tipo de relaciones que establecemos con eso que consideramos nuestro lugar, ofrece el marco de sentido sobre el que se posa esta narración.

La experiencia de Investigación Acción Participativa inició en mayo del 2010 y continúa en la actualidad. En este proceso tanto la fotografía como otras estrategias de expresión y creación artística se han convertido en las herramientas fundamentales de indagación de los jóvenes, construyendo un espacio de investigación-creación, donde se han transformado los temas y cuestionamientos emergentes en el proceso.

El propósito de este artículo, es dar especial relevancia a las voces de los niños, niñas y jóvenes, quienes enriquecen la noción de topofilia, topofobia y proponen un nuevo término: fotofilia. Sus aportes y hallazgos evidencian también sus singularidades, formas particulares de vivir su mundo y de narrar su historia.

\section{CONTEXTUALIZACIÓN}

El lugar donde viven los jóvenes con los que adelantamos esta experiencia, Altos de Cazucá, está surcado por serias y visibles problemáticas de orden social, político y medioambiental, lo cual ha dificultado el óptimo desarrollo de la vida en comunidad. La violencia imperante en la zona ha promovido un estado de temor continuo, y por ende, de poca participación de la comunidad. Sin embargo, desde el 2001 se ha ido conformando un grupo de niñas, niños y jóvenes en torno al trabajo fotográfico y al liderazgo comunitario. Este grupo existe en parte por la gestión y voluntad de dife- rentes personas y organizaciones sociales -en un principio lideradas por la fundación Disparando Cámaras para la Paz- y ahora se sostiene gracias a la persistencia e inquietud de los jóvenes participantes, apoyados por un líder comunitario y colaboradores externos. A lo largo del tiempo se fue presentando la posibilidad de observar con más detenimiento cómo estos jóvenes nombraban sus experiencias de vida y de hábitat, muchas veces condicionados por las complejas características del entorno. En representaciones fotográficas y verbales que hicieron sobre sus contextos abundaron percepciones negativas, sobre la pobreza, fealdad, escasez, vergüenza e inseguridad, etc. De igual forma, parecía que las posibilidades de soñar, en sus entornos, estaban dictadas por el deber ser de los medios masivos y un sentimiento de resignación dado por la noción de "carencia". Este fue el primer motivo para arriesgarnos a trabajar sobre esas percepciones, a través de una estrategia que nos permitiera la acción y reflexión conjuntas, como la Investigación Acción Participativa.

La IAP provee un espacio fértil para comprender cómo son nuestras relaciones con el entorno, y a partir de eso planear en qué forma incidir en ellos, llevando el plan a la acción. Es posible colegir que la transformación de la realidad es el propósito más visible en el diálogo entre la fotografía participativa y la vivencia topofílica. Al seguir la provocación de apropiar los preceptos y metodologías de este tipo de investigación a través de la práctica artística, se hizo fuerte la necesidad de ampliar los esquemas de Investigación Acción Participativa hacia nuevos enfoques. Se hizo imperativo, entonces, generar pequeños procesos de movilización en torno a la revaloración y transformación del espacio habitado, desde el ámbito de la creatividad y la resignificación de nuestras realidades. Términos como imaginación y transformación adquirieron trascendencia en el diálogo cotidiano al interior del grupo, y se aterrizaron en todas las acciones y reflexiones concernientes a la topofilia.

\section{II. ¿QUÉ ES TOPOFILIA?}

El filósofo francés Gastón Bachelard acuñó el término imprimiendo un profundo sentido de intimidad, que sólo podría sentir aquél que puede evocar vívidamente la entrañable calidez de su hogar de infancia. 
“En efecto, en este libro, sólo queremos examinar imágenes muy sencillas, las imágenes del espacio feliz, nuestras encuestas merecerían en esta orientación, el nombre de topofilia. Aspiran a determinar el valor humano de los espacios de posesión, de los espacios defendidos contra fuerzas adversas de los espacios amados. Por razones frecuentemente muy diversas y con las diferencias que comprenden los matices poéticos, son espacios ensalzados....El espacio captado por la imaginación no puede seguir siendo el espacio indiferente, entregado a la medida y a la reflexión del geómetra. Es vívido no en su positividad, sino con todas las parcialidades de la imaginación" (BACHELARD, 1986: 34).

Topofilia alude a la construcción de la poética de nuestra vida, desde el reconocimiento de la emocionalidad que tienen los diferentes espacios -tangibles e intangibles- donde ésta discurre. Los espacios son el escenario donde se presenta la narración, donde se imprime el tono que nuestras dramaturgias personales evocan. El término topoanálisis aparece aquí como el estudio sistemático de los parajes de nuestra vida íntima "En este teatro del pasado que es nuestra memoria, el decorado mantiene a los personajes en su papel dominante. Creemos a veces que nos conocemos en el tiempo, cuando sólo se conocen una serie de fijaciones en espacios de la estabilidad del ser...". (BACHELARD, 1986: 41).

Posteriormente, el geógrafo chino Yi-Fu Tuan enriquece el término involucrando en la construcción de topofilia el fenómeno de la percepción sensorial, teniendo en cuenta cómo los entornos -tanto naturales como urbanos- son filtrados a través de los sentidos del hombre y de cómo esto evoca en él diferentes tipos de relaciones. También inicia una exploración sobre las significaciones culturales de los lugares. La mirada de Yi-Fu Tuan, en comparación al zoom íntimo que genera Bachelard, es más contextual, por tal razón se eleva sobre el objeto inicial del hogar, enriqueciendo la gama de espacios a ser valorados desde una óptica topofílica, para esto pone sobre la mesa una nueva categoría, la de lugar.

La definición que nos ofrece este autor es "el lazo afectivo entre las personas y el lugar o el ambiente circundante. Difuso como concepto, vívido y concreto en cuanto experiencia personal" (TUAN, 2007: 21). Al visibilizar la dimensión de "lazo afectivo" se interpreta que Yi-Fu Tuan propone to- pofilia como una suerte de sentimiento; el sentimiento de apego y apropiación podría ser la filiación relativa a los espacios. Otro aporte del autor a la construcción del concepto, es la derivación que éste hace en "sentimientos" opuestos: al igual que habla de topofilia, también menciona la topofobia, interpretada como la relación negativa con determinados espacios, e incluso la toponegligencia, como la ausencia de vínculos o compromisos con el lugar.

El arquitecto colombiano Carlos Mario Yory diverge especialmente de la propuesta de Yi-Fu Tuan, la cual se puede antojar pasiva al detenerse exclusivamente en la identificación de las filiaciones con el espacio. Para el colombiano, el espacio es en sí una acción inherente al ser humano, en contraposición a la idea de un espacio preexistente, el cual "ocupamos" a través de la emoción. Según Yory, topofilia tiene más que ver con "la propia construcción del espacio de tal forma "abierto" en el acto de habitar que en sí mismo supone una espaciación" (YORY, 2003: 388).

Yory presenta el concepto como una base para la proactividad, propone la posibilidad de transformar el espacio y adelantar acciones positivas sobre éste.

La adaptación del término topofilia que ofrece Yory es "el acto de co-apropiación originaria entre el hombre y el mundo, mediante el cual el mundo se hace mundo en la apertura que de él realiza el hombre, en su naturaleza histórico-espaciante" (Ídem). El espacio, que nace justo en el acto de habitar, es ya un lugar de acción y de realización del hombre. El hombre se hace en el espacio, se enuncia y se hace presente en su humanidad. Y nos convida una nueva definición del concepto espacio: “...no puede establecerse desde una privilegiada y aséptica preexistencia significante a ocupar, sino desde una construcción histórica y social cargada de sentido en la cual se hace patente una determinada relación con el mundo" (Ídem). Se puede interpretar que la topofilia es, pues, un acto creativo que genera espacios en la acción de habitarlos, espacios no sólo físicos, también posibilidades de acción y enunciación del ser humano.

Es interesante ver el desarrollo general del concepto topofilia, que nace en un ámbito poético e íntimo que se pregunta, desde el microcosmos de las ensoñaciones, sobre el hogar; para desembocar a otro ámbito que se amplía y 
abarca los contextos natural y cultural, apoyándose en la percepción sensorial de los distintos lugares. Finalmente, este desarrollo llega a propuestas que, desde la arquitectura y la planeación urbana, reclaman una reconceptualización del término, en vías de permitir la acción, el desarrollo y la transformación tangible de los contextos, en el marco de proyectos de intervención macro.

\section{EL ACTO FOTOGRÁFICO}

La imagen, como medio de representación hace parte de ese conjunto de mecanismos y elementos que se establecen para construir y ofrecer una perspectiva, una idea específica de lo que conocemos como la realidad. La imagen bidimensional, llámese fotografía, dibujo o pintura, y en general el amplio abanico de imágenes que nos provee la experiencia de vivir un mundo móvil, tridimensional y cambiante, van constituyendo el corpus a partir del cual podemos definir, representar y significar el mundo en el que vivimos. Bachelard enriquece la propuesta de imagen para acercarnos a la topofilia. Data sobre las imágenes vívidas del inconsciente, que es necesario traer de nuevo "la casa es un cuerpo de imágenes que dan al hombre razones o ilusiones de estabilidad. Reimaginamos sin cesar nuestra realidad: distinguir todas esas imágenes sería decir el alma de la casa; sería desarrollar una psicología de la casa" (BACHELARD, 1986: 51). El recurso nombrado por el autor es la continua evocación de imágenes, pero no cualquier tipo de éstas, sólo las que trascienden el mero fin descriptivo pueden llevarnos a habitar de nuevo: "Ias verdaderas casas del recuerdo, las casas donde vuelven a conducirnos nuestros sueños, las casas enriquecidas por un onirismo fiel, se resisten a toda descripción. Describirlas equivaldría a jenseñarlas!..." (BACHELARD, 1986: 55). Por supuesto el recuerdo o la evocación no se completan en una sola imagen clara y contundente, más bien se reconstruyen a partir de una sucesión de imágenes escurridizas, aún así cálidas, entrañables. "Pero las imágenes no se acomodan a las ideas tranquilas, ni sobre las ideas definitivas. La imaginación imagina sin cesar y se enriquece con nuevas imágenes. Nosotros quisiéramos explotar esas riquezas del ser imaginado" (BACHELARD, 1986: 30).

Al iniciar la experimentación en torno al diálogo entre topofilia y fotografía, el grupo rápidamente superó el uso do- cumental fotográfico y exploró otros tipos de lenguajes. Los jóvenes se han acercado al problema del arte y la imagen contemporánea más por el reconocimiento de sus propias propuestas e invenciones, que por la deducción teórica sobre el tema. Al utilizar las herramientas de construcción de imágenes como medios de indagación, los participantes se desligaron de preconceptos sobre lo que es artístico y desarrollaron propuestas que explotaron y llevaron a otros lugares su creatividad, ampliando las posibilidades de la fotografía, más allá de lo que estaban acostumbrados a percibir. Así, los niños y jóvenes jugaron con la imagen digital y en papel, interviniéndola de distintas maneras, explorando sus posibilidades como objeto y como imagen (en el juego con la profundidad de campo, ángulos, planos, entre otros elementos del lenguaje visual) para transformar los valores de la realidad que entraba y fluía -líquida- por el lente y el interés de ellos. Experimentaron distintas maneras de componer imágenes que fueran "nuevas" para ellos, siguiendo el compromiso de Carolina Arias, de 13 años (Imagen 1), quien incitó al grupo "tenemos que tomar fotos que asombren a la gente".

También perdieron el temor a explorar otras formas de imagen, al hacer tránsitos entre lo bidimensional y lo corporal (haciendo puestas en escena, pequeños happenings y exploraciones sobre la expresión de sus cuerpos), lo tridimensional (haciendo objetos a partir de ideas evocadas en las fotos), la imagen en movimiento (con el video y el stop motion). Es más, la experiencia con la fotografía poco a poco exigió una fuerte disposición a la acción, y no sólo la acción de obturar, o de perseguir un modelo-objetivo. Implicó a los jóvenes a discutir de manera interminable, entrar en disensos y consensos, organizarse y persistir como grupo, dialogar, entrevistar e interpelar a personas conocidas y desconocidas, caminar por el barrio, hacer grabaciones de audio y video, hacer mapas, textos y gráficos, dramatizar, experimentar con distintos materiales, inventar historias y nuevas acciones, traer recuerdos y narrar sus vidas (Imágenes 2 y 3). La fotografía pasó a ser un acto fotográfico, y en sintonía con la IAP, se convirtió en un medio para visibilizarse políticamente ante la comunidad. 


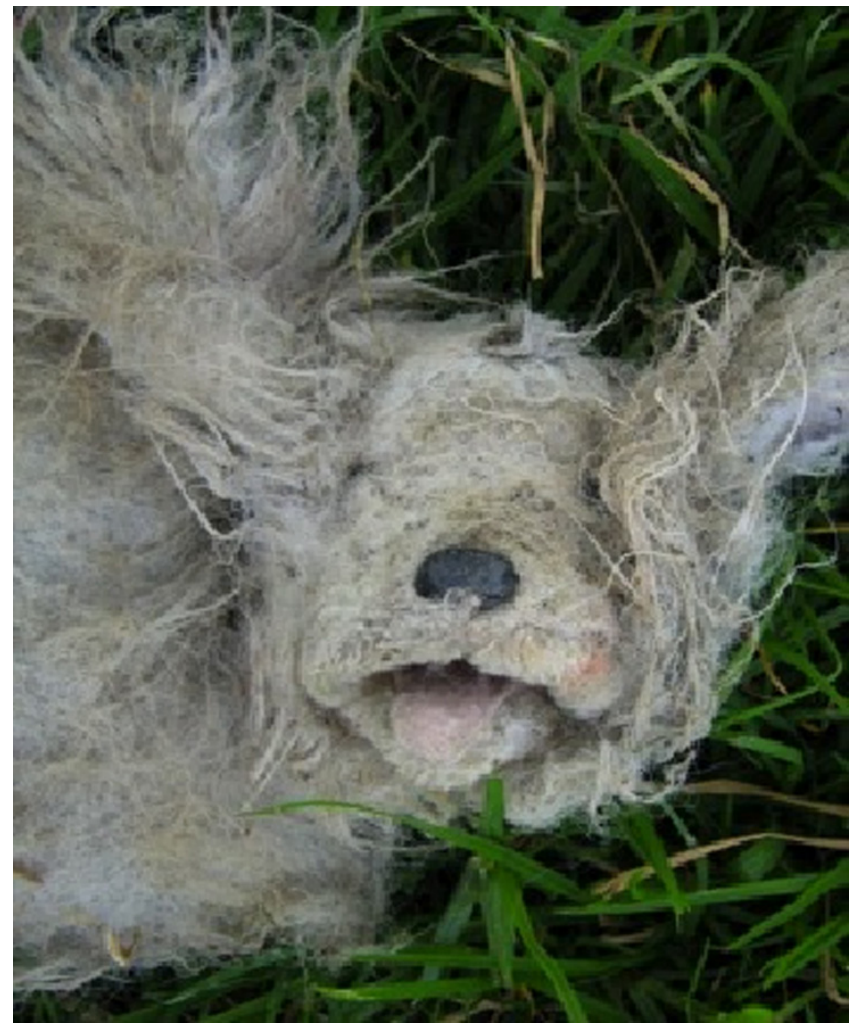

Imagen 1. ARIAS, Carolina (2011) La basura gigante. Fotografía Digital.

La autora narra "Esa foto es de un perro, que era un peluche de Michelle mi hermana, es que mi padrastro se lo regaló y ella lo botó, lo dejó tirado por ahí y yo lo encontré enterrado y después le tomé una foto y le acerqué la cámara, como para que se vea gigante y yo hice eso para que se vea la basura gigante, la basura gigante es... por ejemplo que usted va caminando por la calle y de pronto se encuentra algo pequeñito y a lo que tú te acercas o le tomas una foto, y se hace grande, y pues ahí te salta el perro..."

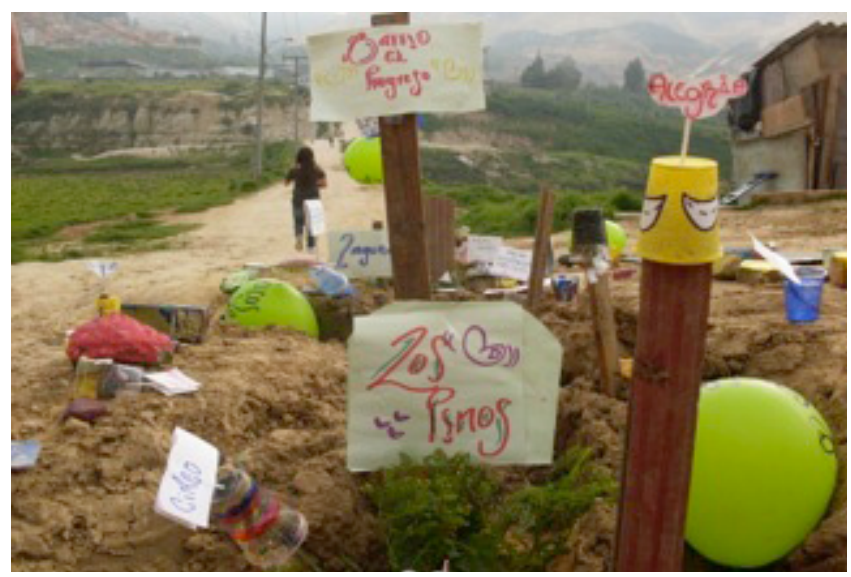

Imagen 2. CORREDOR, Maya (2010). Sin Título. Fotografía digital. Intervención en el espacio realizada con desechos, a partir de un ejercicio de cartografía fotográfica sobre el barrio. Los carteles y letretos identifican algunos lugares evidenciados por los jóvenes en la cartografía, como "Barrio el Progreso" y "Los Pinos". A la derecha, el vaso amarillo con el letrero "Alegría" es utilizado como convención para señalar los lugares agradables para los jóvenes.

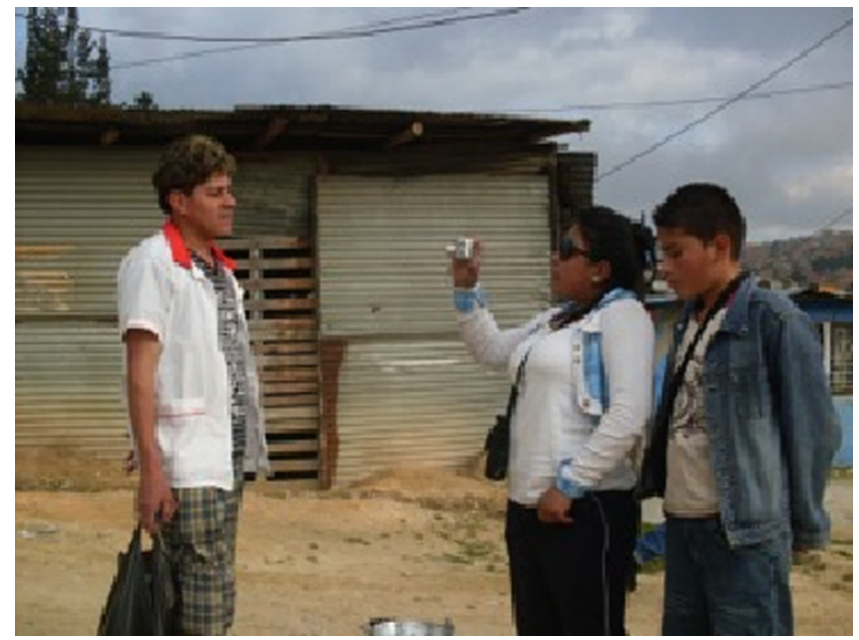

Imagen 3. CORREDOR, Maya (2010) Sin Título. Fotografía digital. Liliana Rodríguez y Camilo Bonilla entrevistan a un habitante del barrio.

A medida que los ciclos del proyecto se desarrollaron, los participantes dieron relieve a los rincones, recuerdos y evocaciones de sus propios hogares, hicieron mapeos fotográficos sobre ciertos lugares de su barrio que les generaban emociones positivas y negativas, se interesaron por visibilizar las transformaciones que la ola invernal hizo en el panorama del barrio, fueron seducidos por captar fotográficamente la mirada macro del paisaje, y la visión micro sobre esos pequeños objetos, antes desapercibidos en la tiranía de la cotidianidad.

Esa búsqueda del detalle perdido en el indiferente "día a día" fue la mejor posibilidad para cristalizar visualmente los hallazgos de los jóvenes respecto a la pregunta por la topofilia, que se decantó en el tema de la basura. Tanto los grandes basureros que posan por meses en cada esquina del barrio, como los diminutos e imperceptibles vestigios del desecho humano en las calles fueron constituyendo el mejor lugar de encuentro entre la topofilia y la fotografía (Imagen 4). Al finalizar el tercer ciclo, los jóvenes apropiaron la fotografía como una forma de conocer el mundo y construyeron nuevos significados sobre la topofilia, la topofobia, el hábitat, el rol social grupal y la responsabilidad individual. Realizaron distintas acciones de visibilización en la comunidad, transitaron del cuestionamiento inicial a la voluntad de transformar sus hábitos personales, medioambientales, y multiplicaron sus aprendizajes al interior de los hogares. 




Imagen 4. ARIAS, Michelle (2011) Sin título. Fotografía digital. Pequeños desperdicios que narran su historia.

Vaso plástico: "Y tu papel, tu de donde salistes"

Papel blanco: "Yo salí de un árbol y vine a Bogotá y esoty contento porque yo fui muy usado"

Vaso plástico: “Oye tu desodorante ¿tú de donde vienes y quién te fabricó?” Desodorante: "Yo estoy triste porque a mí me botaron y no me terminaron de usar".

En este proceso todos hemos adquirido nuevos conocimientos. A partir de la revisión de esta experiencia hemos transformado percepciones y, sobre todo, hemos afinado las intuiciones que nos motivaron hacer parte de este espacio. Por mi parte, presentaré algunas lecturas respecto a esos nuevos lugares que han descubierto los participantes en su indagación sobre la topofilia, a partir de lo que implica el acto fotográfico.

\section{UNA NUEVA INTERPRETACIÓN DE TOPOFOBIA.}

\subsection{La posesión como antítesis de la apropiación topofílica.}

Una de las acciones que resultaron del acto fotográfico, fue un video que hicieron los jóvenes sobre ciertos roles de las personas que conforman la comunidad. Liliana Rodríguez, de 17 años, interpreta a un gestora imaginaria, llamada Zafiro, que es partidaria de excluir de la zona a un grupo de jóvenes que hacen rap "Yo pienso que esos muchachos hay que sacarlos del barrio, no están haciendo algo muy interesante por el barrio, y lo que están haciendo es que el barrio se vuelva peor, y me ha dicho la gente que esos pelados no deben estar en el barrio, entonces yo creo que lo mejor es echarlos (...) porque yo no quiero que el barrio se dañe por muchachos como esos, yo lo que quiero, es llamar a un par de amigos que tengo, y mandarlos a sacar del barrio, porque mi barrio, mi comunidad, no me la dañan, aquí la que manda soy yo y punto".

La labor de este personaje está articulada a un gran sentimiento posesivo, y me permite imaginar una hipótesis sobre el origen de algunos conflictos históricos de los habitantes de esa zona, como los enfrentamientos entre pandillas, las rencillas por la administración de los servicios públicos -que son ilegales en la zona- y el desplazamiento forzado. El origen de tales conflictos estaría relacionado a la noción de posesión del territorio, que puede ser vista aquí como esa necesidad de delimitar el espacio sobre el que se cree tener autoridad, ganada por la antigüedad, la fuerza u otros factores legitimadores. Tales vínculos generan conflictos cuando aquella "posesión" comienza a ser minada por la diversidad y la vida en comunidad, por aquellos otros con los que hasta el momento se había coexistido, mas no convivido. De ahí surgen resoluciones violentas para diluir la presencia de ese Otro; surgen reacciones instintivas, alimentadas por el temor: temor a la pérdida del terreno o a enfrentarse con una nueva autoridad o poder. La posesión sería así una antítesis de la tolerancia y del reconocimiento a la diversidad, también devela una resistencia a transformar las condiciones de vida.

Esta reacción, aunque está relacionada a una fuerte vinculación con la tierra, no fortalece a los sujetos, sino todo lo contrario: diluye, fragmenta y limita; por tanto no puede tener lugar en las relaciones topofílicas. La apropiación (topofílica) aunque en definición es muy cercana a la posesión, tiene en este caso una connotación positiva, ya que se basa en la comunión con el lugar, por ello implica una conciencia sobre la vida del mismo, sobre su "ecosistema social". La topofilia no permitiría una apropiación autoritaria y violenta del espacio, más bien prevería una generación de redes para producir ambientes positivos y creativos.

\subsection{El miedo}

En la cartografía fotográfica emergieron distintas categorías de lugares, como los lugares de gozo, asco, de buenos y malos recuerdos, de interés, amor, seguridad e inseguridad, de historias increíbles, etcétera. A medida que fue construida, 
los lugares de miedo e inseguridad minaron el mapa. Según los jóvenes, el miedo y el temor no son sólo consecuencias de determinados problemas en la comunidad, como la inseguridad. También son el problema en sí mismo ya que muchas veces impiden actuar y crean nuevos conflictos. El miedo desemboca en la desconfianza, vista aquí como un factor que impide la unión de la comunidad. El temor es un opuesto a la tranquilidad, que muchas veces es asumida por los jóvenes como algo lejano y muy preciado. Jesús Armando Buitrago -llamado Chucho por sus compañeros-, de 15 años, menciona "la ausencia de tranquilidad es algo muy fuerte".

\subsection{La soledad}

En un ejercicio de autorretrato, Liliana Rodríguez se fotografió como un personaje de ficción, una niña pequeña y triste, cuya imagen complementó su perfil de Facebook (Imagen 5). Cuando se le preguntó sobre las razones para hacerlo, reconoció que muchas veces se ha sentido así, como alguien solitario en un hogar algo descuidado. La niña de la foto es alguien que detrás de la fortaleza que muestra siempre en público, esconde una niña interna, demandante de cuidados y afecto. Las tardes en los hogares son el momento donde se cruza el ocio y la soledad de los jóvenes.

Ttra Monzters

pregunta del da sque harias o ge pensarias al wer una nena qe pueda tener menos adad quizas unos 8 años ast?

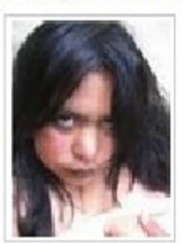

[-3) Hace aproximadamente 4 meses - Me gusta = Comentar secriacioin

A Yiyo Livi le gusta esto.

Q2 Maya Cornedor ¿que no ha comido nadita? 10 de diciembire de 2010 a las $18: 40$ - Mé gusta $B 1$ personá

W1. Tita Monzters pera primero piensa si esta fuera su alma a vida 1. 10 de diciembre de 2010 a las 19:41 - Me qusto

Imagen 5. RODRÍGUEZ, Liliana (2010) Autorretrato. Fotografía digital1.

La soledad muchas veces conlleva al miedo; la ausencia de figuras protectoras, afectuosas y acompañantes en el hogar

${ }^{1}$ Extraído de https://www.facebook.com/photo.php?fbid=135909863132 $238 \&$ set $=0.163583163682914 \&$ type $=1 \&$ theater hace que los jóvenes sientan tal emoción. Las hermanas Wendy y Kelly Pérez decidieron fotografiar esos lugares que les causaban miedo al interior de su casa. A ciertas horas del día y por supuesto, de la noche, la soledad tornaba a la cocina y la sala como lugares macabros (Imagen 6).

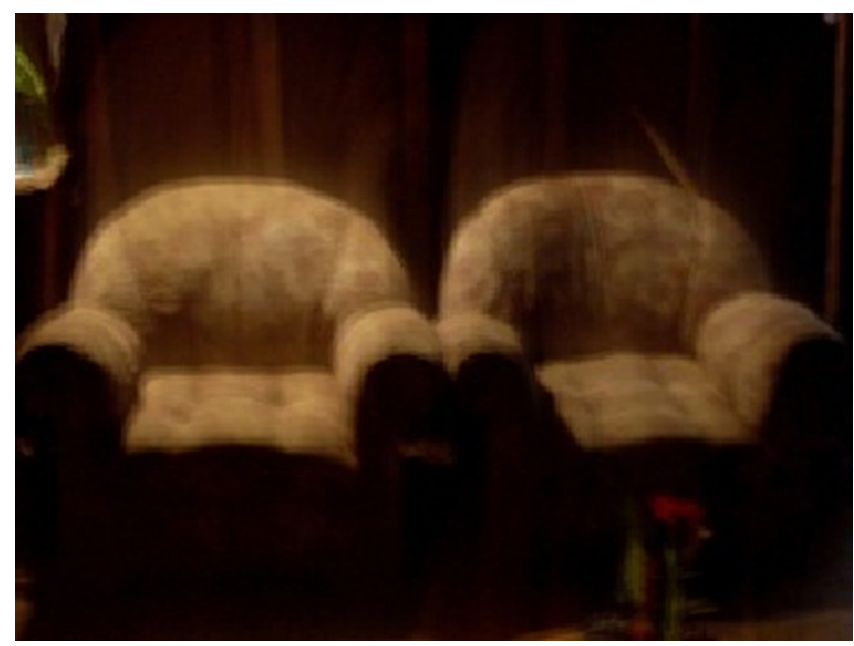

Imagen 6. PEREZ, Kelly (2010) Sin título. Fotografía digital.

\subsection{La desesperanza y la impotencia}

Para identificar las categorías de lugares que orientarían las tomas fotográficas grupales, fue necesario tener largas remembranzas sobre las experiencias positivas y negativas de los jóvenes en el barrio. Muchas de ellas estaban relacionadas a sensaciones de impotencia frente a la violencia. Esta percepción de incapacidad limita la proyección de un horizonte futuro positivo, y hace que la situación negativa se perciba como perpetua. La cotidianidad en un territorio tan violento como Cazucá, le imprime a la vivencia de Julián Granados, de 22 años, una fuerte sensación de desilusión y pesimismo "es muy difícil desarmar a una pandilla hablando". La impotencia también es producida en situaciones de poco empoderamiento de estos jóvenes, en un mundo adulto y autoritario que no los escucha y que limita sus posibilidades de decisión y acción.

La narración que "Chucho" hace al grupo sobre su arribo -como desplazado años atrás- al barrio, expresa una fuerte sensación de desesperanza, al no gozar de una red de apoyo que le suavizara semejante trance “...cuando yo llegué recién a este barrio, no teníamos nada, ni donde estudiar (...) con la desesperación de no tener un hogar, yo me llegué a desesperar y le decía a mi mamá "no mami, eso es muy 
feo, vivir en esta situación, uno que va a hacer, después... de grande" (...) De toda esa negatividad que a uno no lo deja progresar, ajjj quejándose, que "no he comido, que casi no he comido bien", qué pena porque a mí de recién llegado me tocó pedir para poder conseguir una piecita o algo así, y: "aj que feo, que pena ique pensará la gente!" si? Entonces me daba como embarrada y me desanimaba..."

La experiencia de Chucho es similar a la de muchos habitantes de Cazucá que fueron víctimas del desplazamiento forzado, cuando en sus condiciones de vida ocurren cambios abruptos y traumáticos, provocan situaciones de lento reacomodamiento y reconfiguración de sus relaciones de topofilia. La cicatriz es una adecuada metáfora visual del desarraigo topofóbico: hay una fuerte ruptura del tejido topofílico y la reconfiguración del mismo puede llevar bastante tiempo. El barrio y la experiencia de los jóvenes se va surcando por cicatrices.

Es importante observar que, en un primer momento de este proceso, la fotografía sirvió -dentro de la lógica investigativa- para identificar emociones y percepciones de los jóvenes que a veces les era difícil esclarecer y verbalizar. Así, en este inicio se visibilizaron fácilmente malestares y temas que, en la urgencia del conflicto, fueron nombrados como negativos por ellos; de esta manera se contó con información suficiente para interpretar el tema de la topofobia. Sin embargo, en un segundo momento, ya un poco más apropiados de las propiedades expresivas e imaginativas del acto fotográfico, con una identidad grupal más fortalecida y más seguros de su rol como sujetos que interpelan a la comunidad, los jóvenes adoptan una postura más activa para decidir cómo asumir la topofilia.

\section{UNA PROPUESTA DE TOPOFILIA}

\subsection{Lo holístico e integrador}

La topofilia se convirtió en el lugar del cuidado y autocuidado. En los jóvenes se despertó un sentimiento holístico, de comunión con su medio ambiente, una conciencia -todavía incipiente- sobre los múltiples lazos que los unen a su hábitat.

Liliana Rodríguez nos cuenta "Al coger uno conciencia de la basura, uno está cogiendo conciencia de cosas inanima- das, como una botella, porque si uno puede entender una botella ¿porque no puede entender a una persona? Me ha ayudado a entender esas cosas que no pueden y pueden hablar, es como tener conciencia de la gente del barrio, y de otras partes" (Imágenes 7 y 8 ).

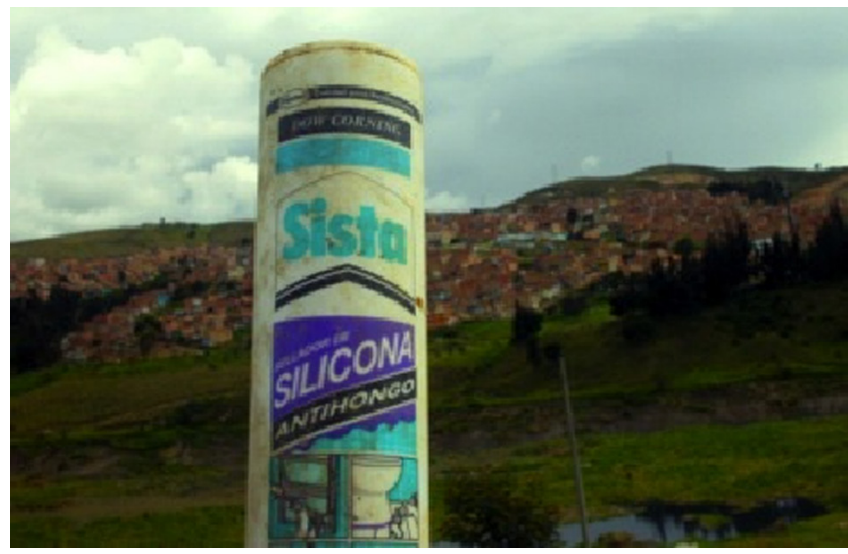

Imagen 7. PEREZ, Kelly (2011) Sin título. Fotografía digital.

Una de las estrategias utilizadas por los jóvenes para detallar los objetos de la basura, fue jugar con el lenguaje visual, para hacer de un pequeño desecho, un descomunal objeto.
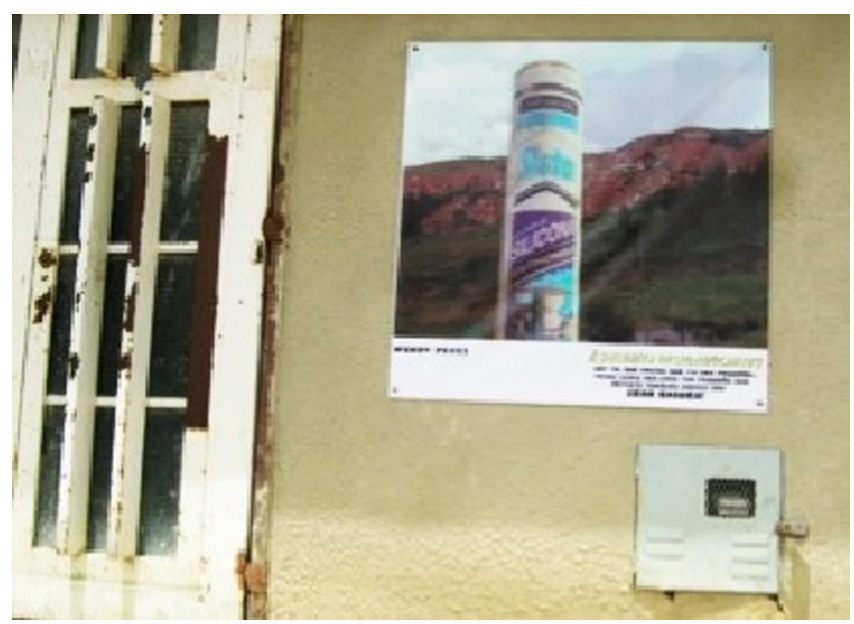

Imagen 8. CORREDOR, Maya (2011) Sin título. Fotografía digital.

Luego, las fotos ampliadas fueron ubicadas en las fachadas de varios hogares del barrio, donde los autores explicaron a los vecinos el sentido de ejercicio.

Chucho menciona "He aprendido a valorar las cosas, que aunque sea un objeto hay que hablarle, hay que tratarlo como... a una persona, que no diga "ah este es un pajarito de palo (un juguete del grupo), dejémoslo por allá o echémoslo a la basura" sino a darle un nombre, hablarle, expresar, cuando esté aburrido y no tenga nada, pues hablar con él, como un amigo..." 
En los abordajes fotográficos que los jóvenes hicieron sobre el tema de la basura, poco a poco fueron asumiéndola como un espacio de sensibilidad, de interés estético y social. En esta experiencia los jóvenes lograron darse cuenta de que algo estaba sucediendo con su percepción sensorial, cuando los ejercicios fotográficos se relacionaron con la basura, los objetos y el paisaje. Se afinaron sus sentidos y se amplió el registro del ecosistema, no sólo respecto a los seres vivos y sociales que lo integran, sino también de los elementos inertes, artificiales, "insignificantes": lo macro y lo micro, lo evidente y lo velado (Imagen 9). Lo inanimado adquirió vida al ser personificado, lo insignificante y micro retumbó a través del lente, lo sucio y "feo" se dignificó a partir de la experimentación plástica, el paisaje fue recorrido, aprehendido.
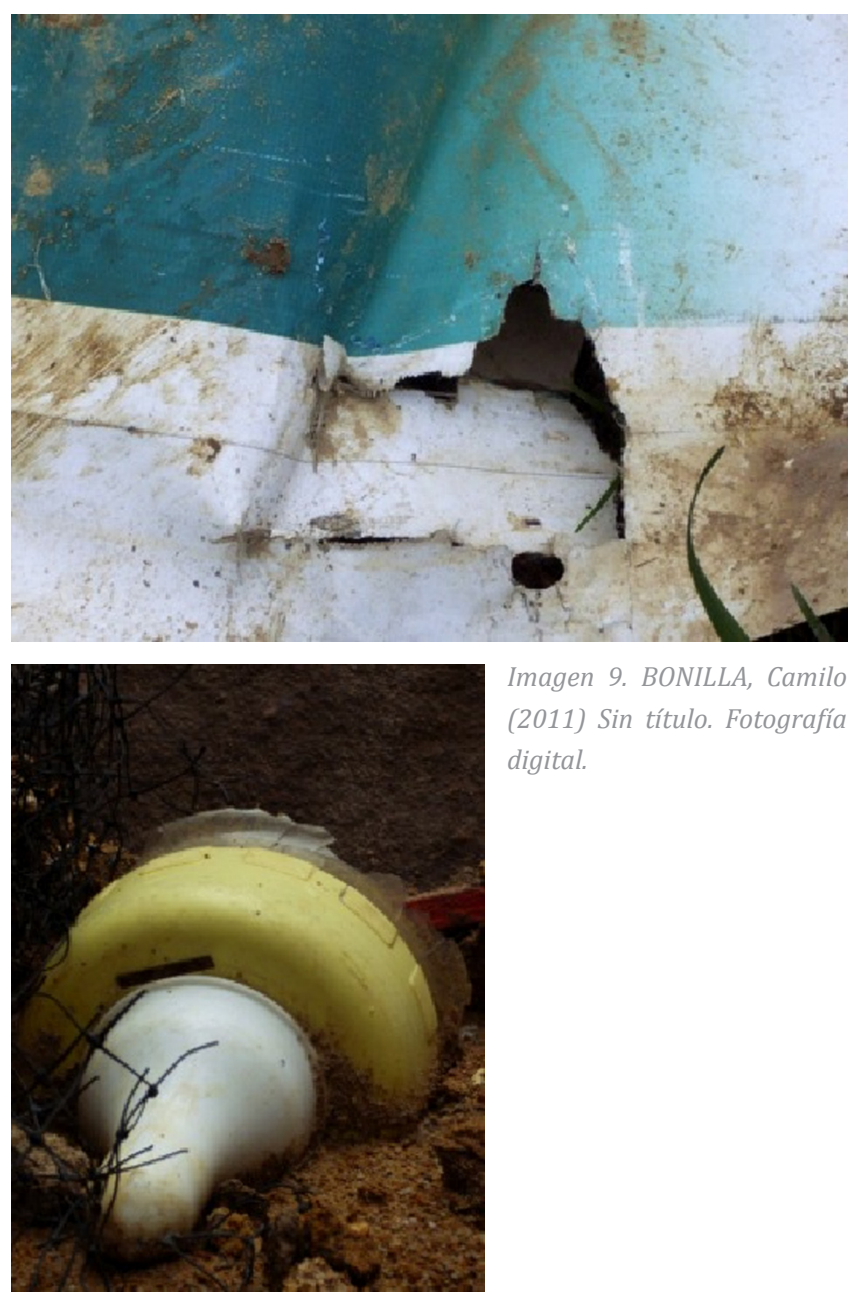

Imagen 9. BONILLA, Camilo (2011) Sin título. Fotografía digital.

Por otra parte, Camilo Bonilla, de 14 años, expresa:

“Mi lugar es todo el barrio, pero sobre todo aquí en mi casa, porque yo me siento aquí con ellos y siento que puedo ha- cer lo que quiera aquí en mi casa (...) pero también el barrio es mi lugar porque uno puede salir con los amigos, uno conoce las calles, se conoce, porque yo vivo aquí desde chiquito, yo conozco este barrio desde chiquito, conozco hasta todos los perritos que viven aquí y todo, si fuera un desconocido no tendría la posibilidad de meterme acá porque no conocería las calles... ese es el barrio donde yo nací, donde yo crecí, donde me crié, porque yo desde chiquito madrugaba pa' la calle, entonces por eso yo digo que es mi santuario y que está en mí. Topofilia es el amor o lo que uno siente por la tierra de uno, lo que uno lleva adentro con el barrio, con el proceso de uno, lo que uno siente cuando toque algo, cuando toque tierra, cuando uno diga "yo aquí naci" "yo siento lo que aquí viví"... ipara mí es eso!. Yo acá siento que soy parte del barrio, que todo el mundo conoce quien soy yo ¿cierto? Yo siento que el barrio es mío porque si yo no me pusiera en lugar del barrio pues el barrio ya estaría muy acabado iya estuviera muerto!, pues por eso yo llevo el barrio dentro de mí, para cuidarlo, respetarlo, quererlo, para hacer respetar al propio barrio, entonces por eso digo que lo llevo dentro de mí, para que él y yo seamos como uno solo" .

“... Antes... digamos... yo veía al barrio lo veía una cosa sucia, veía una porquería, pero ahora lo veo como... como mi santuario, o sea, como si yo fuera parte de él, como si él estuviera dentro de mí."

Y Elainer Arias, de 15 años, añade: "Topofilia tiene que ver con la naturaleza y con el mundo entero"

En las largas jornadas de recorrido fotográfico, de diálogo con los demás integrantes del barrio, en la intervención de espacios antes no frecuentados por ellos, los jóvenes lograron adquirir más confianza y una conciencia más amplia sobre su entorno. Se puede decir que con el acto fotográfico el grupo logró irradiar una suerte de tentáculos de percepción, que abarcaban el conjunto de los elementos de la comunidad, de forma que se sentían mas cómodos, con más dominio sobre el lugar que habitaban. Un sentimiento integrador y global, que abarca, en un plano general, desde el planeta tierra, como mencionó Elainer "con la naturaleza y con el mundo entero" hasta el plano detalle del objeto más pequeño e inanimado que existe en él, como afirma Chucho "aunque sea un objeto hay que hablarle". 
Este nuevo interés exige renovar la sensibilidad "entender esas cosas que no pueden y pueden hablar, es como tener conciencia de la gente del barrio, y de otras partes", según Liliana Rodríguez. También exige una disposición de cariño hacia el hábitat, para apreciarlo como un gran sistema, donde todo está relacionado, conectado en red, un territorio amplio pero así mismo frágil, merecedor de ser cuidado y valorado. Esta noción de lo holístico se irradia también en movimientos hacia el interior del sujeto, como bien dice $\mathrm{Ca}$ milo "por eso yo digo que es mi santuario y que está en mí". Continuando con el tono que provee este ultimo testimonio, también emergieron interpretaciones de topofilia que tomaron como centro de la experiencia al individuo.

\subsection{La topofilia dentro de Mí}

Liliana Rodríguez cuestiona "Si topofilia es el sentimiento de seguridad, de confort y de afecto por el lugar ¿’por qué entonces no puedo yo misma ser mi lugar?"

Continúa “.... mi lugar, mi lugar soy yo misma, porque este cuerpo -o mi topofilia- lo puedo llevar a todas partes, y en cada parte me siento cómoda ¿por qué? Porque he tenido digamos que ... una identidad, y si uno tiene identidad, se va a sentir bien en todas partes! (....) si uno no tiene una identidad definida, uno nunca va a estar bien y va a querer ser como lo otros donde llega, si uno tiene identidad puede conocer personas que me hagan sentir bien y protegida (...) mi topofilia soy yo misma con las personas que me rodean, yo me siento muy bien a donde voy, porque uno es y donde quiera que esté es el mismo y así uno consigue amigos. Topofilia es mi identidad, mi propio yo (...) si me voy de mi casa, de mi cuarto, a donde quiera que llegue sé que me voy a sentir bien porque me siento acompañada conmigo misma, siento esa identidad de que soy yo y soy yo! y nadie va a cambiar mi mentalidad porque eso fue lo que aprendí de mi mamá, de mis profesores, del taller, de todas esas cosas, entonces eso es lo que le queda a uno también"

Liliana reconoce como valor topofílico la confianza en sí misma, la autonomía y la seguridad en su imagen, y provoca un impredecible giro del concepto formulado por Bachelard, Tuan y Yory. Topofilia, para la joven, sería esa contención interna que necesita, su identidad. Necesariamente tiene que llevar ese lugar dentro de sí, teniendo en cuenta los retos y riesgos del exterior, para poder sentirse protegida y cómoda. Liliana es una adolescente que ha logrado situaciones de autoregulación, frente a los retos y condiciones negativas ha logrado construir una propia contención, como una medida de autocuidado, porque ella asume que su bienestar es importante. En ese sentido se puede relacionar visualmente su contención con la protección que ofrecen las paredes y la estructura de la casa frente al ambiente, la delimitación del hogar.

\subsection{El territorio iniciático}

Erika Yate, de 14 años, define "Topofilia puede ser la tierra donde nació, porque ahora hay mucha gente desplazada por los paramilitares, porque piensan que la ciudad es muy dura y extrañan su tierrita, su vaquita, su casita"

Y Chucho reitera sobre su experiencia de desplazamiento:

“... Antes me sentía marcado por la tierra de donde yo salí, ahí me sentía genial, sin ningún peligro o casi ningún sufrimiento. Pero por ese golpe (el desplazamiento forzado) uno se da cuenta que de esos golpes de la vida es cuando uno comienza a fortalecerse más (...). Ahora digo que mi lugar es acá en Bogotá, porque aquí he aprendido muchas cosas, o sea, allá en el campo, claro, si hubiera querido hubiera estudiado, pero no hubiera sido igual, porque me hubiera encargado de la finca, de los animales, de algo que es muy significativo, pero allá yo no entendía muchas cosas, allá uno puede ser trabajador y matarse pero no entender las cosas, entonces yo ahora digo que acá, porque acá fue donde yo empecé una nueva vida, y empecé a entender, a comprender y empecé a desarrollar lo que tengo"

Erika, en sintonía con Bachelard, remite la topofilia a los lugares de la infancia, donde se nace y crece, sin embargo su narración está enmarcada en la actual carencia de esos espacios, por el fenómeno del desplazamiento en el entorno rural colombiano. Chucho, que vivió la situación nombrada por la joven, en una primera instancia se acerca al discurso de Yate, pero luego reivindica su experiencia de desplazamiento y resiliencia y posiciona su actual hogar como "su lugar". Muy relacionada esta idea con la imagen del nacimiento que anuncia Erika, pero desde la concepción del ter- 
ritorio iniciático que ofrece Annah Arendt, quien enuncia al sujeto en un segundo nacimiento, que acontece en la esfera pública a través del discurso y la acción, revelándose ante los demás:

"Acción y discurso están tan estrechamente relacionados debido a que el acto primordial y específicamente humano debe contener la respuesta a la pregunta "¿quién eres tú?". Este descubrimiento de quién es alguien está implícito tanto en sus palabra como en sus actos (...) sin el acompañamiento del discurso, la acción no sólo perdería su carácter revelador, sino también su sujeto (...) aunque su acto pueda captarse en su cruda apariencia física sin el acompañamiento verbal, sólo se hace pertinente a través de la palabra hablada en la que se identifica como actor, anunciando lo que hace, lo que ha hecho y lo que intenta hacer". (ARENDT, 2005: 2002)

Así, Chucho reconoce que su actual lugar de topofilia es aquél donde tuvo la oportunidad de presentarse como ser social, como un ser que construye conocimiento y que es valorado - por sí mismo y los demás- por su habilidad para aprender, para "entender": "porque acá fue donde yo empecé una nueva vida, y empecé a entender, a comprender y empecé a desarrollar lo que tengo".

Así mismo, el reconocimiento público y el fortalecimiento del autoestima producto de estas labores de indagación grupal, afirmaciones nuevos lugares de empoderamiento, en la medida en que los jóvenes se sienten fuertes y seguros en su lugar: un nuevo orgullo se visibiliza en sus formas de expresión. Chucho continúa su narración "Topofilia puede ser: nunca sentirse mal, por ejemplo que alguien lo quiera humillar a uno, pues uno no se debe sentir mal, humillado: "ajjj yo no puedo hacer esa cosa", uno debe tener orgullo en sí mismo, eso de que unos piensan una cosa de mí pero yo pienso otra cosa de mí, si ellos me dijeron que yo no podía hacer algo... pues yo me propongo a hacerlo".

En comparación a los primeros testimonios de Chucho, cuando expresaba la desesperanza que sintió en el desplazamiento, en esta última narración se percibe la fuerza de su enunciación como un sujeto más posicionado, que se asume como centro de su proceso. En la actualidad, este joven es de los más activos y entusiastas fotógrafos del grupo, su familia lo respeta y apoya sus actividades en el barrio. La versión de topofilia expuesta por Carlos Mario Yory se dimensiona en esta experiencia de vida: el sujeto que crea es también un ser que decide y toma posiciones, que genera nuevos espacios (afectivos, participativos, políticos, físicos o intangibles) donde no los hay, es un sujeto que no se resigna a ocupar los ya existentes. Y que hace gala de su potencial para revertir imaginativamente los significados dominantes que median su experiencia como habitante.

\section{LA FOTOFILIA, O EL VÍNCULO ENTRE TOPOFILIA Y EL ACTO FOTOGRÁFICO.}

En uno de los cortes del proceso, los jóvenes verbalizaron sus nuevas percepciones producto de la experiencia con el acto fotográfico. Un aporte valioso que la mayoría realizó es considerar la práctica fotográfica como un medio que afina destrezas para analizar el entorno y para construir conocimiento en colectivo. Otro aporte es el poder sensibilizador hacia el detalle cotidiano antes ignorado (Imagen 10). Igualmente una interiorización del fenómeno fotográfico, que se libera del problema técnico y es aprehendido por ellos como algo orgánico, y como un "modo de ver".

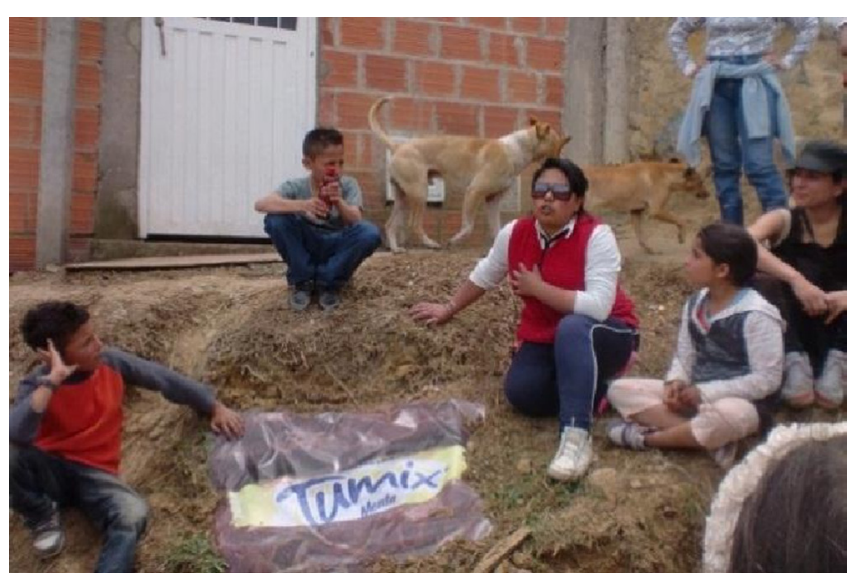

Imagen 10. CAMACHO, Felipe (2011) Sin Título. Fotografía digital. Registro de espacio intervenido con fotografía de Liliana Rodríguez. La autora expone su obra.

Liliana expone "Con la fotografía he captado cosas que nunca pensé, que mi ojo no ve, puedo ver de más esas cosas que no puedo captar con la vista normal (...) Uno con la cámara tiende a volverse loco, yo cojo una cámara y me vuelvo loca, porque siempre veo detalles distintos, o sea es como decir: siempre estoy encontrando cosas, cosas diferentes, digamos, me vuelvo loca para saber que hay, para encontrar cosas, es como una locura de querer querer querer... 
encontrar mas.... pero para el ojo mismo, porque el ojo que quiere captar, que quiere ver, quiere ver diferentes cosas, mi locura es tener sed de eso".

"La fotografía es poder. Es otra forma de expresarse, es mi agenda, mi diario: ¿que yo me veo fea hoy?, pues me tomo una foto, en vez de escribirlo o decirlo. Es una cosa distinta a lo que yo digo, hablo, no puedo mentir, la foto son mis sentimientos. (...) La fotografía es algo que sale muy muy dentro de mi (...) una foto es un espejo, si uno se mira en el espejo uno se trata de arreglar, por eso la foto puede cambiar la mentalidad de la gente, porque si se ve reflejada ahí se puede arreglar, el problema es que hay otra gente que ni por eso despierta"

"La fotografía no es la cámara, la cámara es el instrumento (...) pero para mí la fotografía son los sentimientos y los ojos (...) mis ojos y mi cerebro están conectados, y hay tanta conexión que se conectan a mis sentimientos y pensamientos, todo se conecta que mi cabeza se vuelve una máquina fotográfica, yo juego con la luz, y uno va caminando y va tomando fotos." (Imagen 11)

"Si uno todo el tiempo está buscando su foto perfecta y si uno se la imagina mientras la busca, pues uno va a comenzar a tomar muchas fotos perfectas, y uno busca busca busca y eso es muy bueno porque uno nunca va a encontrar su foto perfecta! La foto perfecta nunca se va a ver porque sería esa foto que a todo ojo le parecería espectacular, pero como todos vemos distinto! Porque uno siempre está cambiando, y entonces con la fotofilia uno estará buscando todo el tiempo su perfección, pero perfecto no es nadie".

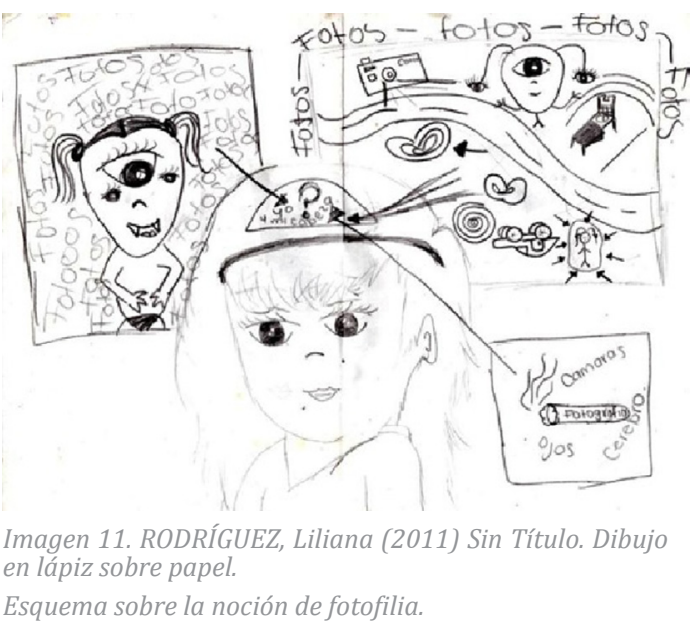

El aprendizaje nació a partir de la dinámica cíclica de sorpresa y hallazgo, de encuentro y desencuentro tan propio de la deriva investigativa. El grupo poco a poco construyó una lógica de investigación-creación, en una suerte de laboratorio de transformación -tanto de materiales como de significados- que aportó significativamente a la metodología de la IAP. Como comenta Wendy Pérez:

"Yo digo que a mí me ha servido para experimentar más cosas, como, no sé, escribir sobre las fotos en acetatos (Imagen 12 y 13), como... dibujar... dejar volar la imaginación con las fotos, por ejemplo, si uno toma una foto de un pedazo de teja pues, uno la transforma, con acetato la transforma, es como experimentar más cosas, no sé, es como un nuevo paso en la vida de nosotros (....) experimentar es aprender nuevas cosas.... Como.... como tomar una nueva fotografía, no la misma de siempre, una nueva imagen, un nuevo retrato (....) tomar una foto a una imagen que nunca antes había visto, algo así, no? Por ejemplo, ya hay muchas imágenes ¿sí? Pero porqué no tomar fotos de esas nuevas imágenes, de esas nuevas cosas. La fotografía me da el poder de saber... aprender y enseñar más cosas a las personas".

Cuando iniciamos formalmente esta indagación, el término topofilia generó sorpresa y curiosidad en los participantes, puesto que nunca lo habían escuchado. Poco a poco se familiarizaron y jugaron a hallar múltiples asociaciones del mismo. Una de las relaciones que más perduró y que fue poco a poco utilizada por ellos, fue la palabra fotofilia, que significó el lugar de encuentro entre lo que habían percibido, hallado y sentido sobre topofilia y la fotografía. Los jóvenes encontraron vínculos prácticos de ambos conceptos, en un solo cuerpo.

La siguiente narración de Liliana Rodríguez reúne las reflexiones que los jóvenes hicieron sobre tal vínculo "Para mí la fotografía y la topofilia son una, la fotofilia. Si la fotografía se esparce y la topofilia también, pues habría un vacío, porque abría un hueco entre las dos, porque cuando se unen esas dos tendría algo más fuerte, si yo tengo la experiencia tengo el talento, y si tengo el talento, pues voy a tener mucha experiencia.... si yo no tengo la topofilia pero sí tengo la fotografía, no voy a sentirme segura de tomar la foto, si en mí misma no me siento bien, o sea no tengo la topofilia, 


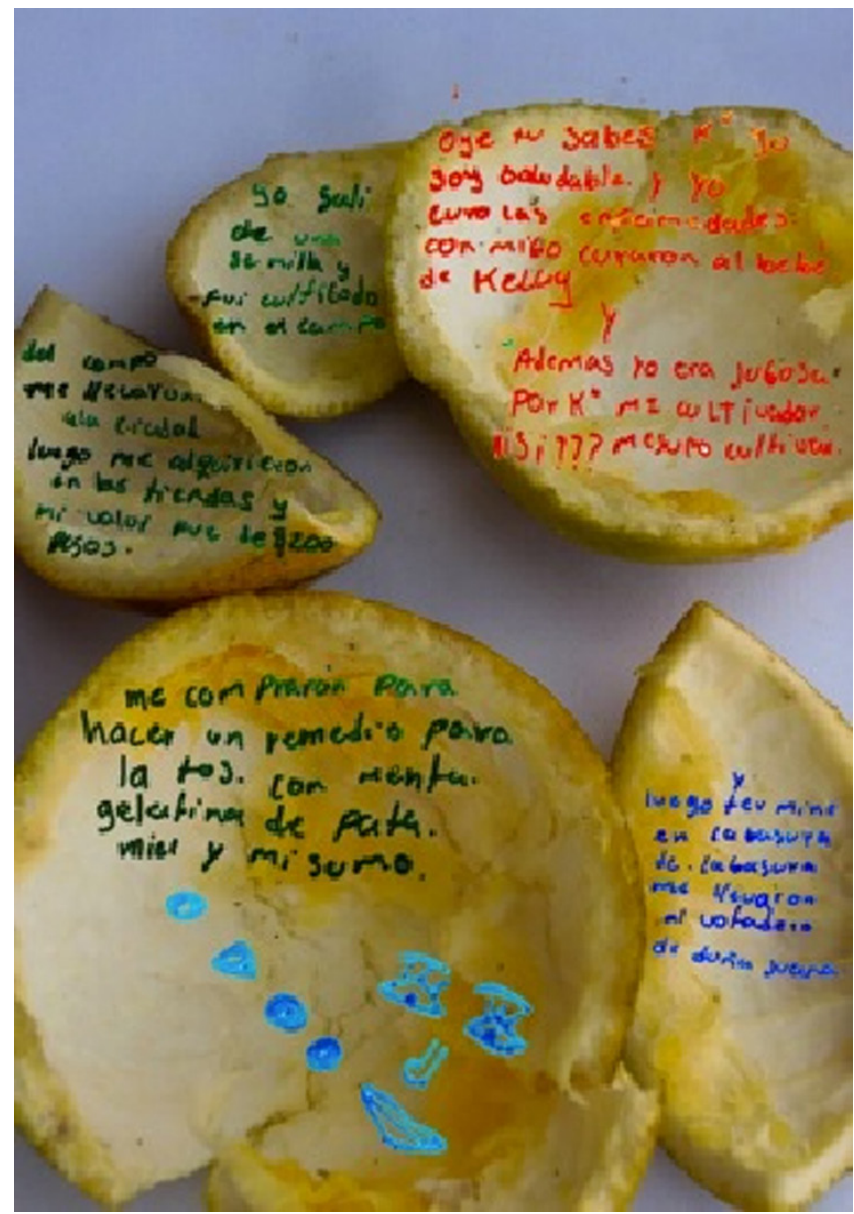

Imagen 12. PEREZ, Wendy (2011) La historia de la Basura. Intervención en fotografía digital.

Las hermanas Perez se dedicaron a tomar fotos de la basura de su hogar luego reconstruyeron su historia.

"Oye tu sabes que yo soy saludable, yo curo las enfermedades, conmigo curaron al bebé de Kelly, y además yo era jugosa porque mi cultivador sí me supo cultivar.

Yo salí de una semilla y fui cultivada en el campo.

Del campo me llevaron a la ciudad, luego me adquirieron en las tiendas y mi valor fue de 200 pesos.

Me compraron para hacer un remedio para la tos. Con menta, gelatina de pata, miel y mi zumo.

Y luego terminé en la basura, de la basura me llevaron al botadero de Doña Juana"

voy a mirar el tarro con defectos, al querer tomarle la foto. ¿Pero si yo la topofilia la tengo en mi casa? ¿Qué hace allá? Allá está mi parte segura, pero si la topofilia es la que me da seguridad, pues yo la tengo que llevar para otros lados"

Camilo Bonilla continúa "la fotografía influye mucho en la topofilia porque cuando yo tomo la foto de una pequeña cosa que yo quiera harto y al día siguiente yo, pues, voy a tener una foto... para recordarla siempre! Para tenerla de recuerdo. También me ha servido para ver esas pequeñas cosas, tan pequeñas que nadie note, para tenerlas ahí para

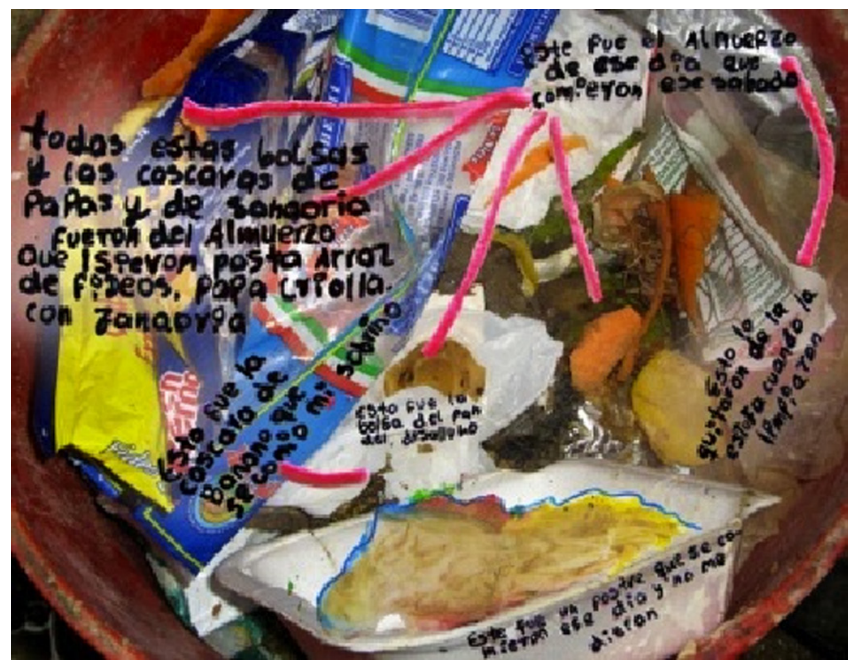

Imagen 13. PEREZ, Erika (2011) La historia de la Basura. Intervención en fotografía digital.

"Este fue el almuerzo que comieron ese día, que comieron ese sábado.

Todas estas bolsas y las cáscaras de papa y de zanahoria fueron del almuerzo que hicieron, pasta, arroz de fideos, papa criolla con zanahoria.

Esta fue la cáscara de banano que se comío mi sobrino.

Esta fue la bolsa de pan del desayuno.

Este fue un postre que se comieron ese día y no me dieron.

Esto lo quitaron de la estufa cuando la limpiaron"

que el mundo diga "ah eso es de mi barrio, yo lo conozco, eso me pertenece!" Entonces la gente mira con esas cosas, que el barrio de ellos se está acabando, que se pueden preocupar por eso (....) si la gente del barrio se preocupara más por el medio ambiente, este barrio sería un paisaje, todo bonito!"

La topofilia es para Liliana su seguridad y contención, y el acto fotográfico es sobre todo un acto de pensamiento "... los sentimientos y los ojos (...) mis ojos y mi cerebro están conectados, y hay tanta conexión que se conectan a mis sentimientos y pensamientos, todo se conecta que mi cabeza se vuelve una máquina fotográfica". Ahí se articulan la mirada, la mente y el sentimiento. Así ella manifiesta necesitar de una presencia de ambas esferas (topofilia y fotografía) para ejercer de forma concentrada, segura y plena el acto fotográfico. Camilo nombra como fotofílico el uso de la fotografía como ese lente que revela los elementos invisibilizados en el sistema vital que lo rodea. Otro aporte es la generación de memoria sobre esos lugares y elementos queridos del entorno, sobre el cual pretende que los demás habitantes adquieran una conciencia más alta, éste sería el último aporte fotofílico del joven. 


\section{CONCLUSIONES}

En esta experiencia pude constatar los intersticios entre la topofilia y la fotografía, ya que ambos conceptos abandonaron su abstracción y se volvieron formas de sentir. La topofilia se volvió afecto puro, se incorporó como un saber y un sentimiento construido a lo largo de la experiencia de los jóvenes; la fotografía se hizo presente como una práctica que para algunos data de varios años, que es afecto porque a través de ella pueden aprehender las emociones, catalizarlas, conservarlas, descubrirlas. Por supuesto, la totalidad de estos jóvenes ama la fotografía, porque es el espacio donde pueden ser ellos mismos, expresarse con libertad, jugar, recordar, pensar. Tanto la topofilia como la fotografía representan un vital movimiento afectivo. Y ese vínculo entre ambos conceptos fue renombrado como fotofilia.

Otros elementos que vinculan topofilia con fotografía es que para los jóvenes, ambos términos significan lugares de enunciación, de orgullo, allí no hay lugar para los malos tratos ni la humillación, como menciona Chucho cuando habla de su topofilia. Son lugares de seguridad y protección. Son lugares construidos por ellos mismos, donde caben lógicas que en otros espacios del entorno cotidiano serían motivo de reproches o incomprensiones. El acto fotográfico y la topofilia (dúo llamado fotofilia) son, finalmente, vínculos de los jóvenes con su entorno, son formas de sentir que ellos hacen parte de, y que a la vez eso hace parte de ellos. La fotofilia es una forma de sentir holística, articulada, relacional de los jóvenes con su espacio circundante.

La fotofilia también tiene la propiedad de correr los velos que no permiten vivir a plenitud la diversidad del entorno. Los jóvenes refrescaron sus formas de percibir a través de sus sentidos, y se sorprendieron ante la magnitud de las múltiples posibilidades de observar y de sentir. Aquí reafirmamos la alegría de relacionarnos -desde el juego- con la riqueza de un entorno antes muerto, como lo era la basura.

En lo político del acto fotográfico, los jóvenes abrieron nuevos espacios al agenciar, actuar y participar activamente. En esta medida la fotofilia habla el mismo lenguaje del concepto de topofilia de Yory, donde el espacio es en sí una acción inherente al ser humano "la propia construcción del espacio de tal forma "abierto" en el acto de habitar que en sí mismo supone una espaciación" (YORY, 2003, 388). Los espacios que realzan Yory y la fotofilia son lugares de acción y de realización de las personas. Con la fotofilia los espacios se expanden también con el poder de la esperanza y la imaginación, superando la resignación con actitudes propositivas.

La fotofilia es fotografía aprehendida, tan interiorizada que es corporeidad, que se vuelve una extensión corporal, una extremidad o un tercer ojo, -como lo sintió Liliana-, que nos conecta con la tierra, a través de su redescubrimiento, que nos hace salir de la verticalidad tanto corporal como actitudinal respecto a nuestro entorno, que nos hace acercarnos, agacharnos, escarbar, reutilizar, revisar, repensar nuestra relación con los objetos.

Por último, la fotofilia es la prueba innegable de que las transformaciones comienzan al interior de los sentimientos, antes que de las racionalidades. Que un aprendizaje racionalmente construido no es aprehendido del todo si no se cruza con la emoción y las fibras internas de ese ser humano investigador. La fotofilia -mezcla extraña entre afecto, racionalidad y técnica- develó que en la emoción de navegar como grupo en una gran marea, logramos conexiones, hicimos redes que se reconfiguraron a cada instante, generando filiaciones con el saber, el sentir y el ser.

\section{REFERENCIAS BIBLIOGRÁFICAS}

ÅHLÉN, E., LAWS, S., \& MANN, G. (2004). So you want to involve children in research? A toolkit supporting children's meaningful and ethical participation in research relating to violence against children. Save the children, Stockholm, Sweden.

ARENDT, H. (2005). La Condición Humana. Paidós, Barcelona.

BACHELARD, G. (1986). La poética del espacio. Breviarios del Fondo de Cultura Económica, México.

BERGER, J. (1980). Mirar. De La Flor, Madrid.

DUBOIS, P. (1986). El acto fotográfico: de la representación a la recepción. Paidós, Barcelona.

ECHEVERRI, P. y HERRERA, A. (2005). La fotografía social como herramienta terapéutica para Trabajo social. Revista Trabajo Social. Universidad Nacional de Colombia, Bogotá. № 7. Páginas 141-160.

HUTZEL, K. (2007). Reconstructing a Community, Reclaiming a Playground: A Participatory Action Research Study. Studies in Art Education: A Journa of Issues and Research in Art Education, Vol. 48, N. 3. The Ohio State University, Ohio. Páginas 299-315. 
LADDAGA, R. (2006) Estética de la emergencia. La formación de otra cultura de las artes. Adriana Hidalgo Editora, Buenos Aires.

SALAZAR, M. C. (2005). La Investigación Acción Participativa. Inicios y Desarrollos. Magisterio, Bogotá.

SONTAG, S. (1997). Sobre la Fotografía. Alfaguara, Buenos Aires.

(2003) La fotografía: Breve Suma. El Malpensante. N48. Páginas 50-52.

TUAN, Y. (2007). Topofilia, un estudio de las percepciones, actitudes y valores sobre el entorno. Melusina, Barcelona.

YORI, C. M. (1993). Topofilia, una alternativa en torno a la revolución de las pequeñas cosas. Alcaldía Mayor de Santa Fé de Bogotá y Programa de las Naciones Unidas para el Desarrollo PNUD, Bogotá.

(1998). Topofilia; Una estrategia para hacer ciudad desde sus habitantes. Universidad Pontificia Javeriana, Bogotá.

(1999). Topofilia o la dimensión poética del habitar. Centro Editorial Javeriana CEJA. Pontificia Universidad Javeriana e Instituto Colombiano para el Fomento a la Ciencia y la Tecnología COLCIENCIAS, Bogotá.

- (2003). Topofilia, ciudad y territorio: Una Estrategia pedagógica de desarrollo urbano participativo condimensión sustentable para las grandes metrópolis de América latina en el contexto de la Globalización. "El caso de la ciudad de Bogotá". Universidad Complutense de Madrid, Madrid.

UNICEF. (2008). Arte y Ciudadanía. El aporte de los proyectos artístico culturales a la construcción de ciudadanía de niños, niñas y adolescentes. UNICEF, Buenos Aires.

\section{NOTA:}

Articulo basado en "Fotofilia. Experiencia de Investigación Acción Participativa en torno al hábitat y la fotografía con un grupo de niños, niñas y jóvenes de Altos de Cazucá", trabajo de grado desarrollado entre 2006-11. Universidad Pedagógica Nacional de Colombia.

AGRADECIMIENTOS a los jóvenes Jesús Armando Buitrago, Liliana Rodríguez, Julián Granados, Kelly, Wendy y Erika Pérez, John Rodríguez, Diana Farfán, Deisy Ñustes, Alejandro Ocampo, Elainer, Carolina y Michelle Arias, Erika Yate, Lucero y Vicky Luna, y Camilo Bonilla. Con quienes construí este espacio de investigación participativa, y quienes lo nutren actualmente. 